\title{
Bagaimana Komitmen Organisasional Memediasi Pengaruh Karakteristik Pekerjaan dan Employee Engagement terhadap Kinerja
}

\author{
Fanny Monica H Bedagama, Endang Tjahjaningsih ${ }^{\bowtie}$ \\ Universitas Stikubank, Indonesia \\ e-mail: naning@edu.unisbank.ac.id
}

\begin{abstract}
This study aims to analyze the effect of job characteristics and employee engagement on performance by mediating organizational commitment to employees of PT Jati Luhur Agung Semarang. The research sample was all 115 employees of PT Jati Luhur Agung Semarang (Factory 1) with census sampling technique. The data analysis technique used instrument test, model test, regression test, and sobel test using SPSS 24 software. The results showed that job characteristics had no effect on organizational commitment. Employee engagement had a positive effect on organizational commitment. Job characteristics had a positive effect on performance. Employee engagement had a positive effect on performance. Organizational commitment had a positive effect on performance. Organizational commitment does not mediate the effect of job characteristics on performance while organizational commitment mediates employee engagement on performance.
\end{abstract}

Keywords: job characteristics, employee engagement, organizational commitment, performance

\begin{abstract}
Abstrak
Penelitian ini memiliki tujuan untuk menganalisis pengaruh karakteristik pekerjaan dan employee engagement terhadap kinerja dengan mediasi komitmen organisasional pada karyawan PT Jati Luhur Agung Semarang. Sampel penelitian adalah seluruh karyawan PT Jati Luhur Agung Semarang (Pabrik 1) berjumlah 115 orang dengan teknik pengambilan sampel secara sensus. Teknik analisis data menggunakan uji instrumen, uji model, uji regresi, serta uji sobel menggunakan software SPSS 24. Hasil penelitian menujukkan bahwa karakteristik pekerjaan tidak berpengaruh terhadap komitmen organisasional. Employee engagement berpengaruh positif terhadap komitmen organisasional. Karakteristik pekerjaan berpengaruh positif terhadap kinerja. Employee engagement berpengaruh positif terhadap kinerja. Komitmen organisasional berpengaruh positif terhadap terhadap kinerja. Komitmen organisasional tidak memediasi pengaruh karakteristik pekerjaan terhadap kinerja sementara komitmen organisasional memediasi employee engagement terhadap kinerja.

Kata kunci: karakteristik pekerjaan, employee engagement, komitmen organisasional, kinerja
\end{abstract}




\section{PENDAHULUAN}

Suatu perusahaan membutuhkan karyawan yang mampu bekerja lebih baik dan lebih cepat, sehingga diperoleh kinerja yang tinggi. Kinerja yang optimum dapat dinilai dengan adanya hasil kerja yang secara kualitas dan kuantitas mampu dicapai karyawan dalam melaksanakan tugas sesuai dengan tanggung jawab yang diberikan atau dapat disebut dengan karakteristik pekerjaan. Karakteristik pekerjaan memiliki tujuan untuk mengatur penugasan kerja yang memenuhi kebutuhan organisasi, teknologi, dan keperilakuan yang menjadi pedoman dalam bekerja sehingga dalam pengkotakan karakteristik pekerjaan ini dapat menghasilkan harmoni dalam suatu organisasi yang terbuka dan terukur serta kemajuan dalam organisasi tersebut. Ananda \& Sunuharyo (2018) menjelaskan bahwa karakteristik pekerjaan berpengaruh terhadap kinerja karyawan.

Tanggung jawab yang diberikan kepada karyawan tidak lepas karena adanya ikatan yang diberikan suatu organisasi atau perusahaan yang sering kali disebut dengan employee engagement. Employee engagement sangat erat kaitannya dengan kinerja karyawan karena setiap anggota dalam suatu organisasi perlu merasa adanya ikatan yang kuat dengan organisasi sehingga adanya rasa bahwa apa yang dikerjakan adalah suatu yang penting dalam organisasi tersebut. Karyawan memiliki harapan atas pekerjaan yang dilakukan karena ada kejelasan yang diperoleh. Employee engagement terjadi karena adanya kesepakatan yang dibuat oleh organisasi dan karyawan tersebut. Siswono (2016) menyatakan bahwa employee engagement memiliki pengaruh yang positif terhadap kinerja.

Komitmen organisasional mampu mengembangkan kemampuan serta memberikan kesempatan bagi seluruh anggota organisasi untuk meningkatkan kinerja. Komitmen organisasional sebagai keinginan kuat untuk tetap menjadi anggota suatu organisasi, keinginan untuk bekerja keras sesuai harapan organisasi, keyakinan tertentu, serta penerimaan nilai dan tujuan organisasi. Komitmen organisasional merefleksikan loyalitas karyawan pada organisasi dan proses berkelanjutan di mana anggota organisasi mengekspresikan perhatiannya terhadap organisasi dan keberhasilan serta kemajuan yang berkelanjutan.

Hasil penelitian Affandy (2016) menunjukkan bahwa karakteristik pekerjaan berpengaruh terhadap kinerja karyawan. Sebaliknya, hasil penelitian Heriyawan \& Setyowati (2015) dan Mulyanto dkk. (2014) menunjukkan bahwa karakteristik pekerjaan tidak berpengaruh terhadap kinerja. Selanjutnya hasil penelitian Siswono (2016) menyatakan bahwa employee engagement memiliki pengaruh yang positif terhadap kinerja, namun berbeda halnya dengan penelitian Joushan dkk. (2015) yang menyatakan bahwa employee engagement tidak memiliki pengaruh terhadap kinerja karyawan. Selanjutnya, hasil penelitian Ekayanti dkk. (2019), Martono dkk. (2017), dan Huang dkk. (2016) menunjukkan bahwa karakteristik pekerjaan berpengaruh positif dan signifikan terhadap komitmen organisasional. Namun demikian, hasil penelitian Purwanto \& Soliha (2017) menyatakan bahwa karakteristik pekerjaan tidak berpengaruh terhadap komitmen organisasional. Hanaysha (2016) dan Astuti \& Khoirunnisa (2018) menyatakan bahwa employee engagement berpengaruh positif terhadap komitmen organisasional, sedangkan penelitian yang dilakukan oleh Jones (2018) dan Albdour \& Altarawneh (2014) menyatakan bahwa employee engagement tidak berpengaruh terhadap komitmen organisasional.

Tidak hanya komitmen organisasional saja, kinerja juga merupakan faktor penting dalam menentukan keberhasilan suatu perusahaan. Menurut penelitian yang dilakukan oleh Atmojo (2015) dan Pradana \& Swasto (2014), komitmen organisasional berpengaruh secara positif dan signifikan terhadap kinerja karyawan, namun hasil penelitian 
dari Suparyanto \& Wahyudi (2011) menyatakan bahwa komitmen organisasional mempunyai pengaruh tidak langsung terhadap kinerja pegawai. Dari perbedaan hasil penelitian-penelitian tersebut, peneliti tertarik mengambil komitmen organisasional sebagai variabel independen dalam penelitian ini, sedangkan komitmen organisasional sebagai variabel intervening dalam penelitian ini.

Pada fenomena di atas, karakteristik pekerjaan, employee engagement, kinerja karyawan, dan komitmen organisasional merupakan suatu hal yang dinilai cukup penting untuk menjamin keberlangsungan perusahaan. Oleh sebab itu, penelitian ini menggunakan kinerja sebagai variabel dependen. Sebagai variabel independennya adalah karakteristik pekerjaan dan employee engagement, sedangkan untuk variabel pemediasinya adalah komitmen organisasional pada PT Jati Luhur Agung Semarang.

PT Jati Luhur Agung Semarang merupakan salah satu perusahaan yang bergerak di bidang lantai kayu parket dan berlokasi di Semarang, Jawa Tengah. Pada awalnya perusahaan hanya memakai kayu jati sebagai bahan utama. Seiring berjalannya waktu, perusahaan memperluas bisnisnya dengan menggunakan beberapa bahan kayu lain yang tersedia di Indonesia seperti kayu karet, Akasia, Mahoni, Sungkai, dan Merbau, sambil berinovasi dan berinvestasi dalam teknologi serta memperluas produk untuk memenuhi permintaan dari pasar Eropa lainnya dan USA. Dalam hal pengelolaan karyawan, PT Jati Luhur Agung Semarang menerapkan kebijakan pengangkatan karyawan dengan masa kerja tertentu, yakni tahapan kontrak selama maksimal 3 tahun atau 2 kali ikatan kontrak. Pengangkatan karyawan tidak selalu diadakan untuk setiap tahunnya, namun berdasarkan pertimbangan kebutuhan tiap departemen, kinerja, dan pertimbangan lain yang perlu dilakukan oleh perusahaan. Tabel 1 menunjukkan data jumlah karyawan PT Jati Luhur Agung Semarang selama 6 tahun terakhir (tahun 2015 hingga 2020).

Tabel 1. Jumlah Karyawan Kontrak (KK) dan Karyawan Tetap (KT) PT Jati Luhur Agung Semarang (Pabrik 1 dan Pabrik 2)

\begin{tabular}{lrrrrrrrrrrrr}
\hline \multirow{2}{*}{ Departemen } & \multicolumn{2}{c}{$\mathbf{2 0 1 5}$} & \multicolumn{2}{c}{$\mathbf{2 0 1 6}$} & \multicolumn{2}{c}{$\mathbf{2 0 1 7}$} & \multicolumn{2}{c}{$\mathbf{2 0 1 8}$} & \multicolumn{2}{c}{$\mathbf{2 0 1 9}$} & \multicolumn{2}{c}{$\mathbf{2 0 2 0}$} \\
\cline { 2 - 11 } & KT & KK & KT & KK & KT & KK & KT & KK & KT & KK & KT & KK \\
\hline Red File & 31 & - & 31 & - & 29 & - & 28 & 1 & 28 & 1 & 27 & 1 \\
HRD - GA & 28 & 14 & 30 & 10 & 30 & 15 & 30 & 20 & 26 & 9 & 19 & 4 \\
Raw Material & 105 & 16 & 99 & 22 & 88 & 25 & 75 & 25 & 65 & 18 & 86 & 19 \\
Produksi & 102 & 7 & 101 & 7 & 115 & 6 & 124 & 6 & 126 & 3 & 101 & 3 \\
Finishing & 69 & 6 & 69 & 6 & 68 & 7 & 67 & 7 & 73 & 6 & 73 & 8 \\
Mechanic & 10 & 5 & 11 & 5 & 16 & 9 & 22 & 13 & 20 & 16 & 21 & 12 \\
Gudang & 6 & - & 6 & 1 & 8 & 1 & 12 & 1 & 9 & 1 & 11 & 1 \\
QC & 4 & - & 4 & - & 5 & 2 & 6 & 4 & 9 & 5 & 8 & 4 \\
\hline \multicolumn{1}{c}{ TOTAL } & 355 & 48 & 351 & 51 & 359 & 65 & 364 & 77 & 356 & 59 & 346 & 52 \\
\hline
\end{tabular}

Sumber: PT Jati Luhur Agung Semarang (2020)

PT Jati Luhur Agung Semarang untuk mempertahankan dan mengembangkan perusahaan perlu memahami baik dari sisi tenaga kerja, kebijakan perusahaan, dan strategi organisasi. Penting bagi perusahaan untuk memahami karakteristik pekerjaan karyawan sehingga mampu memberikan sumbangsih dalam mewujudkan keberhasilan perusahaan serta memberikan umpan balik yang tepat dari perusahaan kepada karyawan. Dengan begitu, karyawan akan mengetahui seberapa efektif dalam bekerja. Kinerja perusahaan sebagai akumulasi dari kinerja kelompok, sedangkan kinerja kelompok itu sendiri merupakan akumulasi dari kinerja individu. Hal lain yang berkaitan dengan karakteristik pekerjaan, yakni employee engagement. Employee engagement berpengaruh terhadap besar kecilnya 
kinerja yang diberikan oleh karyawan terhadap tanggung jawab pekerjaan untuk perusahaan. Komitmen organisasional juga merupakan faktor penting dalam menentukan keberhasilan suatu perusahaan. Tabel 1 menunjukkan bahwa jumlah pekerja selama 6 tahun terakhir dapat dikatakan stabil karena tidak terdapat kenaikan dan penurunan yang signifikan. Hal ini mengidentifikasikan bahwa perusahaan PT Jati Luhur Agung Semarang memiliki komitmen organisasional serta karyawan memiliki engaged terhadap perusahaan. Tabel 2 menunjukkan target dan realisasi kinerja perusahaan dalam melakukan proses ekspor selama 5 tahun terakhir.

Tabel 2. Target dan Realisasi Kinerja

Perusahaan dalam Proses Ekspor PT Jati Luhur Agung Semarang (Pabrik 1)

\begin{tabular}{cccc}
\hline Tahun & $\begin{array}{c}\text { Target } \\
\text { (Container) }\end{array}$ & $\begin{array}{c}\text { Realisasi } \\
\text { (Container) }\end{array}$ & $\begin{array}{c}\% \\
\text { Realisasi }\end{array}$ \\
\hline 2016 & 125 & 123 & 98,4 \\
2017 & 150 & 142 & 94,7 \\
2018 & 117 & 110 & 94,0 \\
2019 & 100 & 46 & 46,0 \\
2020 & 100 & 88 & 88,0 \\
\hline
\end{tabular}

Sumber: PT Jati Luhur Agung Semarang (2020)

Berdasarkan Tabel 2 terlihat bahwa terjadi penurunan kinerja dalam proses ekspor dari tahun 2016 sampai dengan tahun 2020 di mana target tidak bisa terlampaui, realisasi lebih rendah daripada hasil yang ditargetkan. Penurunan kinerja perusahaan ataupun organisasi merupakan akumulasi dari kinerja kelompok, sedangkan kinerja kelompok itu sendiri merupakan akumulasi dari kinerja individu. Berdasarkan fenomena kinerja pada bisnis PT Jati Luhur Agung Semarang dan riset gap maka dalam penelitian ini menggunakan variabel independen karakteristik pekerjaan dan variabel employee engagement. Sementara itu, variabel dependen yang digunakan adalah variabel kinerja, adapun variabel pemediasi menggunakan variabel komitmen organisasional. Tujuan penelitian ini untuk menganalisis pengaruh karakteristik pekerjan dan employee engagement terhadap komitmen organisasional, karakteristik pekerjan dan employee engagement terhadap kinerja, komitmen organisasional terhadap kinerja. Tujuan selanjutnya adalah bagaimana komitmen organisasional memediasi pengaruh karakteristik pekerjan dan employee engagement terhadap kinerja.

\section{Kinerja}

Kinerja karyawan merupakan suatu hasil yang dicapai oleh pekerja dalam pekerjaannya menurut kriteria tertentu yang berlaku untuk suatu pekerjaan tertentu. Kinerja karyawan merupakan sejauh mana seseorang melaksanakan tanggung jawab dan tugas kerjanya (Singh dkk., 1996). Cardoso Gomes (1995) mengatakan performa pekerjaan adalah catatan hasil atau keluaran (outcomes) yang dihasilkan dari suatu fungsi pekerjaan tertentu atau kegiatan tertentu dalam suatu periode waktu tertentu. Kinerja pada dasarnya merupakan hasil kerja seorang karyawan selama periode tertentu. Berhasil tidaknya kinerja karyawan dipengaruhi oleh tingkat kinerja dari karyawan secara individu maupun kelompok. Kinerja menjadi tolok ukur keberhasilan suatu organisasi yang menaungi sebagai perwujudan kerja yang dilakukan oleh karyawan. Gibson (2000) menjelaskan dimensi kinerja dibagi menjadi tiga, yaitu kualitas, kuantitas pekerjaan, dan efisiensi pekerjaan.

\section{Karakterisitk Pekerjaan}

Karakteristik pekerjaan adalah upaya mengidentifikasikan karakteristik tugas dari pekerjaan, bagaimana karakteristik itu digabung untuk membentuk pekerjaan yang berbeda dengan hubungannya dengan motivasi, kepuasan kerja, dan kinerja karyawan (Oldham \& Hackman, 2005). Karakteristik pekerjaan dapat membantu membedakan pekerjaan yang "baik" dan pekerjaan yang "buruk." Banyaknya pendekatan untuk meningkatkan kualitas mencerminkan usaha untuk meluaskan satu karakteristik pekerjaan atau lebih. 
Karakteristik pekerjaan berkaitan dengan pekerjaan itu sendiri dan cara bagaimana karyawan menilai tugas-tugas yang ada dalam pekerjaannya. Menurut Oldham \& Hackman (2010) ada lima dimensi karakteristik pekerjaan, yaitu skill variety (variasi keterampilan), task identity (identitas/kejelasan tugas), task significance (kekhususan tugas), autonomy (kewenangan dan tanggung jawab), dan feed back (umpan balik).

\section{Employe Engagement}

Kahn (1990) menyatakan bahwa employee engagement sebagai keterikatan anggota organisasi dengan organisasi itu sendiri, bukan hanya secara fisik dan kognitif tetapi bahkan secara emosional dalam hal kinerjanya. Employee engagement adalah suatu keadaan psikologis yang stabil dan hasil interaksi antara seorang individu dengan lingkungan tempat individu bekerja (Kaswan, 2019). Employee engagement menciptakan hubungan kuat dengan setiap karyawannya. Hubungan ini juga akan membuat karyawan untuk fokus pada pencapaian yang ingin dituju, membangun kerjasama tim yang solid, serta tidak lupa untuk mengucapkan terima kasih dan apresiasi atas pencapaian antardivisi. Pendekatan dengan employee engagement menghilangkan pemikiran jenuh dan negatif dari setiap masalah yang dihadapi oleh karyawan dalam kehidupannya. Menurut Scott (2005), terdapat tiga dimensi employee engagement yang digunakan, yakni pengabdian, semangat, dan keterampilan kepemimpinan.

\section{Komitmen Organisasional}

Komitmen organisasional menurut Allen \& Meyer (1990) didefinisikan sebagai sebuah keadaan psikologi yang mengkarakteristikkan hubungan karyawan dengan organisasi atau implikasinya yang mempengaruhi apakah karyawan akan tetap bertahan dalam organisasi atau tidak. Tidak berbeda dengan teori sebelumnya, Robbins \& Judge (2008) menjelaskan bahwa komitmen organisasional sebagai suatu keadaan di mana seorang karyawan memihak organisasi tertentu serta tujuantujuan dan keinginannya untuk mempertahankan keanggotaan dalam organisasi tersebut. Komitmen organisasional mempunyai peran penting karena dapat mendorong rasa keterikatan dan loyalitas dari seorang karyawan untuk perusahaannya dan juga sebagai pendorong untuk berkinerja secara maksimal. Komitmen karyawan terhadap organisasinya merupakan suatu hal yang sangat penting sebab tanpa komitmen yang kuat, karyawan hanya akan bertindak sebagai oportunitis. Komitmen organisasional adalah sikap yang mencerminkan keterikatan seorang individu dengan organisasi tertentu dalam hal identifikasi dengannya atau keterlibatan didalamnya. Menurut Allen \& Mayer (1990), komitmen organisasional terdiri dari tiga dimensi yaitu komitmen afektif (affective commitment), komitmen berkelanjutan (continuance commitment), dan komitmen normatif (normative commitment).

\section{Pengaruh Karakteristik Pekerjaan terhadap Komitmen Organisasional}

Keberhasilan perusahaan dalam penentuan job description yang jelas pada karyawan dan sesuai kemampuan akan memberikan dampak yang baik sehingga karyawan memiliki komitmen tinggi terhadap perusahaan dan memberikan dampak yang baik. Penelitian yang dilakukan oleh Ekayanti dkk. (2019) dan Purwanto \& Soliha (2017) menunjukkan bahwa karakteristik pekerjaan mempengaruhi komitmen organisasional. Komitmen organisasional yang tinggi diperoleh dari adanya perpaduan lima faktor karakteristik pekerjaan yang mendorong pegawai untuk tidak meninggalkan organisasinya. Menurut Robbins \& Judge (2008), karakteristik pekerjaan adalah sebuah pendekatan dalam merancang pekerjaan yang menunjukkan bagaimana pekerjaan didiskripsikan ke dalam lima dimensi inti, yaitu (1) keanekaragaman keterampilan, (2) identitas 
tugas, (3) arti tugas, (4) otonomi, dan (5) umpan balik. Hubungan positif antara karakteristik pekerjaan dengan komitmen organisasional ditunjukkan dengan komitmen organisasional yang tinggi akan terlihat pada pegawai yang memiliki karakteristik pekerjaan yang baik. Jika karakteristik pekerjaan pegawai kurang diperhatikan, maka komitmen organisasional tersebut akan turun. Semakin tinggi karakteristik pekerjaan, semakin tinggi komitmen organisasional. Berdasarkan uraian tersebut maka dapat dihipotesiskan sebagai berikut:

\section{$\mathrm{H}_{1}$ : Karakteristik pekerjaan berpengaruh positif terhadap komitmen organisasional}

\section{Pengaruh Employee Engagement terhadap Komitmen Organisasional}

Karyawan akan melibatkan dan mengekspresikan diri secara fisik, kognitif, dan emosional selama bekerja di perusahaan, sedangkan komitmen organisasional merupakan derajat di mana seorang karyawan mengidentifikasikan dirinya dengan organisasi tertentu beserta tujuannya dan berkeinginan untuk mempertahankan keanggotaannya di dalam organisasi tersebut. Semakin kuat ikatan yang diberikan perusahaan oleh karyawan dengan adanya employee engagement, maka karyawan diharapkan memiliki komitmen yang tinggi terhadap perusahaannya. Penelitian yang dilakukan oleh Hanaysha (2016), Haryanto dkk. (2018), dan Astuti \& Khoirunnisa (2018) menunjukkan bahwa employee engagement memiliki pengaruh yang positif dan signifikan terhadap komitmen organisasional. Semakin tinggi employee engagement, semakin tinggi komitmen organisasional. Berdasarkan uraian tersebut maka dapat dihipotesiskan sebagai berikut:

\footnotetext{
$\mathrm{H}_{2}$ : Employee engagement berpengaruh positif terhadap komitmen organisasional
}

\section{Pengaruh Karakteristik Pekerjaan terhadap Kinerja}

Karakteristik pekerjaan memiliki peran yang sangat penting terkait dengan berbagai sikap dan perilaku karyawan di dalam menyelesaikan tugas pokok dan fungsinya. Karakteristik pekerjaan akan meningkatkan kinerja pegawai melalui identifikasi karakteristik pekerjaan yang terkait dan sesuai. Selain itu, karakteristik pekerjaan mampu memberikan penjelasan bagaimana struktur kerja akan mempengaruhi sikap dan perilaku karyawan terhadap kondisi kerja. Simamora (2004) menyatakan bahwa sebuah pekerjaan diperkaya dengan dimensi yang tinggi dan pada akhirnya menciptakan keadaan psikologis kritis yang tinggi dalam diri karyawan. Keadaan psikologis demikian yang akan menghasilkan motivasi kerja yang tinggi, kepuasan kerja yang tinggi, serta ketidakhadiran yang rendah. Penelitian Affandy (2016) dan Ananda \& Sunuharyo (2018) menyimpulkan bahwa karakteristik pekerjaan berpengaruh positif dan signifikan terhadap kinerja. Semakin tinggi karakteristik pekerjaan, semakin tinggi kinerja. Berdasarkan uraian tersebut maka dapat dihipotesiskan sebagai berikut:

$\mathrm{H}_{3}$ : Karakteristik pekerjaan berpengaruh positif terhadap kinerja

\section{Pengaruh Employee Engagement terhadap Kinerja}

Armstrong (2012) menyatakan bahwa, "Secara sederhana, engagement berarti merasa positif terhadap pekerjaan." Pegawai yang engaged adalah pegawai yang semangat, yang secara total tenggelam dalam pekerjaannya, energik, berkomitmen, dan berdedikasi penuh. Dengan kata lain, engagement pekerjaan terjadi ketika pegawai melakukan usaha-usaha sukarela karena mereka menemukan pekerjaan yang menarik, menantang, dan berguna. Didukung oleh hasil penelitian yang dilakukan oleh Siswono (2016) yang menyimpulkan bahwa employee engagement memiliki pengaruh yang positif dan signifikan terhadap kinerja pegawai. 
Semakin tinggi employee engagement, semakin tinggi kinerja. Berdasarkan uraian tersebut, maka dapat dihipotesiskan sebagai berikut:

\section{$\mathrm{H}_{4}$ : Employee engagement berpengaruh positif terhadap kinerja}

\section{Komitmen Organisasional Berpengaruh terhadap Kinerja}

Kaswan (2019) menjelaskan bahwa dalam mengembangkan sumber daya manusia yang unggul dan memiliki kinerja tinggi, perusahaan harus mengintegrasikan empat sistem pengembangan sumber daya manusia, yakni rekrutmen dan hiring, pelatihan dan pengembangan, manajemen kinerja, serta perencanaan karir. Salah satu cara mengembangkan perusahaan atau organisasi yakni dengan memberikan komitmen dari perusahaan kepada karyawannya yang disebut dengan komitmen organisasional. Adanya kepercayaan yang tinggi oleh karyawan maka kinerja karyawan kepada perusahaan juga akan meningkat. Penelitian yang telah dilakukan oleh Atmojo (2015) menunjukkan bahwa komitmen organisasional berpengaruh besar terhadap peningkatan kinerja karyawan, begitu pula dengan hasil penelitian Pradana \& Swasto (2014) yang menyimpulkan bahwa semakin tinggi komitmen organisasional maka semakin tinggi pula kinerja karyawan.

$\mathrm{H}_{5}$ : Komitmen organisasional berpengaruh positif terhadap kinerja

\section{Komitmen Organisasional Memediasi Pengaruh Karakteristik Pekerjaan terhadap Kinerja}

Karakteristik pekerjaan merupakan sifat khas yang melekat pada suatu pekerjaan yang meliputi keragaman tugas, keragaman keahlian atau skill, identitas tugas, dan otonomi (Simamora, 2004). Organisasi perlu memahami bagaimana karakteristik pekerjaan yang diperlukan oleh organisasi dan juga para karyawannya sehingga dapat memuaskan karyawannya. Penelitian yang telah dilakukan oleh Mulyani \& Soliha (2014) menunjukkan bahwa komitmen organisasional memediasi karakteristik pekerjaan terhadap kinerja. Demikian juga hasil penelitian yang dilakukan oleh Riyanto \& Rozak (2016) yang menyimpulkan komitmen organisasional memediasi pengaruh karakteristik pekerjaan terhadap kinerja pegawai di Dinas Perdagangan Kota Semarang. Berdasarkan uraian tersebut, maka dapat dihipotesiskan sebagai berikut:

$\mathrm{H}_{6}$ : Komitmen organisasional memediasi pengaruh karakteristik pekerjaan terhadap kinerja

\section{Komitmen Organisasional Memediasi Pengaruh Employee Engagement terhadap Kinerja}

Schaufeli \& Bakker (2004) menjelaskan bahwa engagement merupakan keadaan pikiran yang positif dan bahagia mengenai pekerjaan yang ditandai dengan semangat, dedikasi, dan penyerapan. Keterikatan emosi yang tinggi antara karyawan terhadap perusahaan dapat mempengaruhi karyawan dalam menyelesaikan pekerjaan (cenderung memiliki kualitas kerja yang memuaskan) dan berdampak pada rendahnya keinginan karyawan untuk meninggalkan pekerjaan atau perusahaan dan rendahnya turnover, serta meningkatkan kepuasan, produktivitas, dan kinerja. Penelitian yang telah dilakukan oleh Winowoda (2018) menemukan bahwa pengaruh employee engagement terhadap kinerja karyawan secara langsung lebih besar daripada pengaruh tidak langsung. Di lain sisi, penelitian yang dilakukan oleh Hakim (2018) menemukan bahwa semakin baik dari employee engagement pada karyawan akan meningkatkan komitmen organisasi dan berdampak pada peningkatan kinerja karyawan. Berdasarkan uraian tersebut, maka dapat dihipotesiskan sebagai berikut:
$\mathrm{H}_{7}$ : Komitmen organisasional memediasi pengaruh employee engagement terhadap kinerja


Berdasarkan uraian tersebut, maka dapat dijabarkan dengan model grafis sebagaimana tertera pada Gambar 1.

\section{Model Matematis}

$Y_{1}=\alpha_{1}+\beta_{1} \cdot X_{1}+\beta_{2} \cdot X_{2}+e_{1}$

$Y_{2}=\alpha_{2}+\beta_{3} \cdot X_{1}+\beta_{4} \cdot X_{2}+\beta_{5} \cdot Y_{1}+e_{2}$
Keterangan:

$\begin{array}{ll}\mathrm{Y}_{1} & : \text { Komitmen Organisasional } \\ \mathrm{Y}_{2} & : \text { Kinerja } \\ \alpha_{1}, \alpha_{2} & : \text { Konstanta } \\ \mathrm{X}_{1} & : \text { Karakteristik Pekerjaan } \\ \mathrm{X}_{2} & : \text { Employee Engagement } \\ \beta_{1}, \ldots, \beta_{5} & : \text { Koefisien Variabel Independen } \\ \mathrm{e}_{1}, \mathrm{e}_{2} & : \text { Residuals atau error }\end{array}$

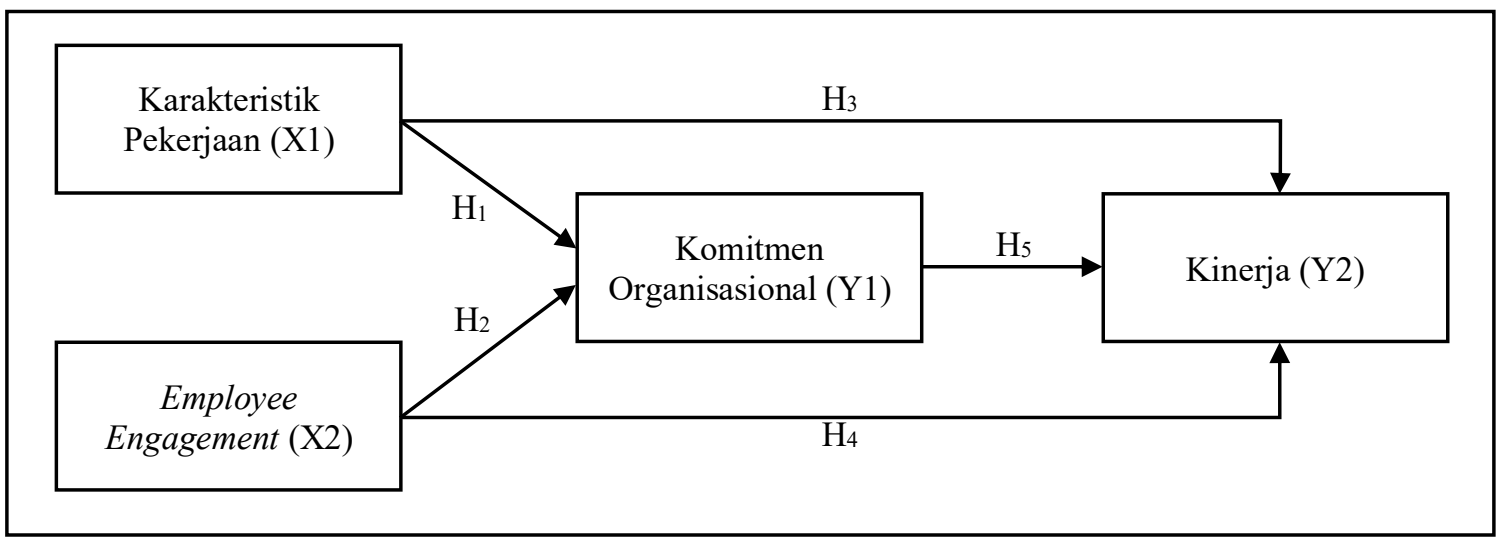

Gambar 1. Model Penelitian Empirik

\section{METODE PENELITIAN}

\section{Populasi dan Sampel}

Populasi dalam penelitian ini adalah seluruh karyawan PT Jati Luhur Agung Semarang (Pabrik 1) dengan jumlah 115 orang dengan kualifikasi jabatan dari tingkat pelaksana, fungsional, hingga struktural, berusia antara 18 tahun sampai dengan 55 tahun dengan masa kerja lebih dari atau sama dengan 2 tahun. Teknik pengambilan sampel dengan sensus. Metode pengumpulan data menggunakan kuesioner kepada responden untuk memperoleh data primer. Daftar pertanyaan diberikan kepada responden secara langsung dengan diberikan batas waktu pengisian kurang lebih 15 menit dan kuesioner yang telah diisi dikembalikan secara langsung kepada peneliti. Kuesioner merupakan alat ukur yang berupa daftar pertanyaan-pertanyaan dalam angket dibuat dengan menggunakan skala Likert 1-5 untuk mendapatkan data yang bersifat interval dan diberi skor atau nilai. Dengan demikian, pertanyaan dapat dijawab dengan lebih mudah oleh responden dengan hanya memberikan tanda pada skala 1-5 yang sudah tersedia, di mana skala 1 diartikan "sangat tidak setuju" dan skala 5 diartikan "sangat setuju."

\section{Teknik Analisis Data}

Teknik mengolah data dilakukan menggunakan analisis deskriptif dan analisis statistika. Analisis deskriptif untuk mengetahui gambaran umum responden. Analisis statistika digunakan untuk menjawab pertanyaan penelitian dengan cara menganalisis dan menguji model empirik dengan regresi berganda menggunakan bantuan software SPSS 24 .

\section{HASIL DAN PEMBAHASAN Deskripsi Responden}

Data mayoritas responden dalam penelitian ini yakni jenis kelamin laki-laki sebesar $54,8 \%$, rentang usia 38-47 tahun sebesar $49,6 \%$, tingkat pendidikan terakhir yang ditempuh SMA sebesar 90,4\%, dan sudah bekerja selama $>20$ tahun sebesar $75,7 \%$.

\section{Uji Instrumen}

Hasil pengujian validitas menunjukkan tiap variabel memiliki nilai KMO yang lebih dari 0,5 sehingga dapat dinyatakan bahwa syarat kecukukupan sampel telah terpenuhi 
dan loading factor yang keseluruhan lebih dari 0,4 pada setiap indikatornya menunjukkan semua indikator valid sehingga dapat dilakukan analisis lebih lanjut. Hasil pengujian reliabilitas menunjukkan bahwa karakteristik pekerjaan memiliki nilai Cronbach's Alpha sebesar 0,816; employee engagement sebesar 0,851 ; komitmen organisiasional sebesar 0,902; dan kinerja sebesar 0,943 sehingga semua variabel yang digunakan dalam penelitian memiliki nilai Cronbach's Alpha diatas 0,7 dinyatakan reliabel.

\section{Uji Hipotesis}

Hasil uji hipotesis ditunjukkan dengan melihat nilai standardized koefisien $\beta$ pada nilai signifikansi kurang dari 0,05. Hipotesis 1 menyatakan karakteristik pekerjaan berpengaruh positif terhadap komitmen organisasional. Karakteristik pekerjaan memiliki nilai $\beta=0,031$ dengan nilai signifikansi $0,801>0,10$ yang berarti $\mathrm{H}_{1}$ ditolak. Hipotesis 2 menyatakan bahwa employee engagement berpengaruh positif terhadap komitmen organisasional dapat diterima. Hal ini terbukti bahwa employee engagement memiliki nilai $\beta=0,647$, tingkat signifikansi $0,000<0,05$. Hipotesis 3 yaitu karakteristik pekerjaan berpengaruh positif terhadap kinerja. Karakteristik pekerjaan memiliki nilai $\beta=0,399$ dengan nilai signifikansi $0,000<0,05$, sehingga $\mathrm{H}_{3}$ diterima. Hipotesis 4 yaitu employee engagement berpengaruh positif terhadap kinerja. Employee engagement memiliki nilai $\beta=0,153$ dengan nilai signifikansi 0,05 $<0,099<0,10$ sehingga $\mathrm{H}_{4}$ diterima pada signifikansi 0,10 (marginal signifikan). Hipotesis 5 menyatakan bahwa komitmen organisasional berpengaruh positif terhadap kinerja. Komitmen organisasional memiliki nilai $\beta=0,751$ dengan nilai signifikansi $0,000<0,05$ yang mengartikan bahwa $\mathrm{H}_{5}$ dapat diterima.

\section{Uji Sobel}

Hipotesis 6 yang menyatakan bahwa komitmen organisasional memediasi pengaruh karakteristik pekerjaan terhadap kinerja ditolak. Karakteristik pekerjaan berpengaruh terhadap kinerja, artinya secara langsung berpengaruh, tetapi $\mathrm{H}_{1}$ ditolak sehingga tidak perlu dilakukan uji mediasi.

Hipotesis 7 menyatakan bahwa komitmen organisasional memediasi pengaruh employee engagement terhadap kinerja memberikan hasil full mediation karena pengaruh employee engagement terhadap kinerja signifikan. Hasil uji sobel menunjukkan nilai $Z=5,7614$ dengan nilai signifikansi $0,000<0,05$. Hal ini menunjukkan bahwa komitmen organisasional memediasi employee engagement terhadap kinerja. Dengan kata lain, untuk meningkatkan kinerja, lebih efektif melalui komitmen organisasional daripada secara langsung.

\section{Karakteristik Pekerjaan Tidak Berpengaruh terhadap Komitmen Organisasional}

Karakteristik pekerjaan tidak berpengaruh terhadap komitmen organisasional PT Jati Luhur Agung Semarang. Hasil penelitian ini memberikan gambaran bahwa karakteristik pekerjaan yang dilakukan oleh PT Jati Luhur Agung Semarang belum cukup optimal dalam mencapai komitmen organisasional yang ada di perusahaan. Karakteristik pekerjaan dideskripsikan ke dalam lima dimensi, yakni keanekaragaman keterampilan, identitas tugas, arti tugas, otonomi, dan umpan balik. Pekerjaan yang mampu menunjukkan keterampilan, kemampuan dalam menyelesaikan pekerjaan, serta kebebasan, dan adanya umpan balik terhadap pekerjaan akan lebih disukai oleh karyawan, sedangkan pekerjaan yang cenderung monoton dan tidak memberi kesempatan kepada karyawan untuk mengeksplorasi kemampuannya akan mengakibatkan menurunnya komitmen organisasional yang ada. Dalam penelitian ini, adanya penyelesaian pekerjaan dengan waktu yang cepat sangat menekan karyawan dan karyawan sendiri memandang perlunya pekerjaan bagi pengembangan diri 
karyawan sangat dipelukan pada perusahaan. Penelitian ini mendukung temuan Purwanto \& Soliha (2017) yang menjelaskan bahwa jika karakteristik pekerjaan karyawan kurang diperhatikan, maka komitmen organisasional karyawan tersebut akan menurun.

\section{Employee Engagement Berpengaruh Positif dan Signifikan terhadap Komitmen Organisasional}

Employee engagement berpengaruh terhadap komitmen organisasional pada perusahaan PT Jati Luhur Agung Semarang. Hasil penelitian ini menunjukkan bahwa karyawan sudah baik dalam mengoptimalkan komitmen organisasional yang ada. Hal ini dapat diketahui dari demografi yang ada di PT Jati Luhur Agung Semarang, yakni sebagian besar karyawan telah bekerja diatas 20 tahun. Begitu besarnya karyawan yang memiliki waktu yang lama bekerja di perusahaan ini mengindikasikan bahwa adanya kepercayaan yang besar dari karyawan ke perusahaan dan dari perusahaan ke karyawan yang menyebabkan tingginya employee engagement terhadap komitmen organisasional yang ada di PT Jati Luhur Agung Semarang. Penelitian ini mendukung temuan Hanaysha (2016) dan Astuti \& Khoirunnisa (2018). Semakin tinggi employee engagement, semakin tinggi pula komitmen organisasional yang terjadi pada sebuah perusahaan. Begitu pula jika menurunnya atau bahkan tidak adanya employee engagement dalam suatu perusahaan, maka komitmen organisasional pun akan menurun dan tidak akan terbentuk.

\section{Karakteristik Pekerjaan Berpengaruh Positif dan Signifikan terhadap Kinerja}

Karakteristik pekerjaan berpengaruh terhadap kinerja pada perusahaan PT Jati Luhur Agung Semarang. Hasil penelitian ini memberikan gambaran bahwa karyawan mampu mengoptimalkan kinerja yang ada di perusahaan. Hal ini disebabkan karena karakteristik pekerjaan yang diukur dengan skill variety (variasi keterampilan) yang merupakan suatu keterampilan dan bakat yang berbeda dari karyawan, task identity (identitas tugas), dan task significance (signifikansi tugas) merupakan kontribusi terhadap kinerja. Hasil penelitian ini mendukung temuan hasil penelitian Affandy (2016) dan Ananda \& Sunuharyo (2018) yang menyimpulkan bahwa karakteristik pekerjaan berpengaruh positif dan signifikan terhadap kinerja. Karakteristik akan meningkatkan kinerja karyawan melalui identifikasi karakteristik pekerjaan yang terkait dan sesuai sehingga mampu memberikan penjelasan bagaimana struktur kerja yang nantinya akan mempengaruhi sikap dan perlaku karyawan terhadap kondisi kerja, yakni kinerja masing-masing karyawan. Meningkatnya kinerja karyawan akan meningkatkan kinerja perusahaan.

\section{Employee Engagement Berpengaruh Positif dan Signifikan terhadap Kinerja}

Employee engagement berpengaruh positif dan signifikan terhadap kinerja yang ada di PT Jati Luhur Agung Semarang. Hasil penelitian ini memberikan gambaran bahwa karyawan memiliki semangat yang tinggi dan berdedikasi sepenuhnya terhadap pekerjaan yang dilakukan. Dalam penelitian ini bahwa karyawan memerlukan kesempatan jenjang karir yang baik, perlunya pemberian umpan balik, membutuhkan penghargaan seperti pemberian selamat dari atasan jika karyawan berprestasi, keterlibatan karyawan terhadap perusahaan, dan pemberian kepercayaan oleh atasan kepada bawahan. Penelitian ini mendukung hasil penelitian yang dilakukan oleh Siswono (2016) yang menyimpulkan bahwa employee engagement memiliki pengaruh yang positif dan signifikan terhadap kinerja pegawai. Jika employee engagement diperhatikan, maka kinerja karyawan tersebut akan meningkat. 
Komitmen Organisasional Berpengaruh Positif dan Signifikan terhadap Kinerja

Komitmen organisasional berpengaruh positif dan signifikan terhadap kinerja yang ada di PT Jati Luhur Agung Semarang. Hasil penelitian ini menunjukkan bahwa dengan pegawai sangat senang menghabiskan sisa perjalanan karir di organisasi ini, antusias membicarakan masalah-masalah yang dihadapi organisasi kepada pihak luar, merasa masalah yang terjadi di organisasi adalah masalah bagi pegawai juga, memiliki ikatan emosional dengan organisasi, sangat berat meninggalkan organisasi meskipun menginginkannya, tidak memiliki niat sedikitpun untuk meninggalkan organisasi, bekerja lebih baik untuk keberhasilan organisasi, organisasi ini merupakan tempat terbaik untuk mengembangkan karir, dan pegawai peduli terhadap keberhasilan organisasi akan berkontribusi dalam meningkatkan kinerja. Karyawan memiliki komitmen organisasional yang tinggi bila memiliki kepercayaan dan menerima tujuan dan menilai organisasi, keinginan untuk berusaha kearah pencapaian tujuan organisasi, dan memiliki keinginan yang kuat untuk bertahan sebagai anggota organisasi. Karyawan yang memiliki komitmen dan kesetiaan yang tinggi akan bekerja dengan optimal demi mencapai kinerja yang baik. Penelitian ini mendukung temuan Atmojo (2015) dan Pradana \& Swasto (2014) yang menunjukkan bahwa komitmen organisasional berpengaruh positif dan signifikan terhadap kinerja.

Tabel 3. Ringkasan Analisis Regresi Persamaan (1) dan Persamaan (2)

\begin{tabular}{|c|c|c|c|c|c|c|c|}
\hline \multirow{2}{*}{ Keterangan } & \multicolumn{3}{|c|}{ Uji Model } & \multicolumn{3}{|c|}{ Uji Hipotesis } & \multirow{2}{*}{ Hasil } \\
\hline & Adj R $\mathbf{R}^{2}$ & $\mathbf{F}$ & Sig. & $\boldsymbol{\beta}$ & $\mathbf{t}$ & Sig & \\
\hline Persamaan (1) & 0,319 & 27,684 & 0,000 & & & & \\
\hline Karakteristik Pekerjaan dan & & & & & & & \\
\hline Employee Engagement terhadap & & & & & & & \\
\hline Komitmen Organisasional & & & & & & & \\
\hline$Y 1=0,031 X_{1}+0,647 X_{2}$ & & & & & & & \\
\hline Karakteristik Pekerjaan terhadap & & & & 0,031 & 0,252 & 0,801 & $\mathrm{H}_{1}$ Ditolak \\
\hline Komitmen Organisasional & & & & & & & \\
\hline $\begin{array}{l}\text { Employee Engagement terhadap } \\
\text { Komitmen Organisasional }\end{array}$ & & & & 0,647 & 6,998 & 0,000 & $\mathrm{H}_{2}$ Diterima \\
\hline Persamaan (2) & 0,645 & 70,126 & 0,000 & & & & \\
\hline Karakteristik Pekerjaan, Employee & & & & & & & \\
\hline Engagement, dan Komitmen & & & & & & & \\
\hline Organisasional terhadap Kinerja & & & & & & & \\
\hline$Y 2=0,399 X_{1}+0,153 X_{2}+0,751 Y_{1}$ & & & & & & & \\
\hline Karakteristik Pekerjaan terhadap & & & & 0,399 & 3,856 & 0,000 & $\mathrm{H}_{3}$ Diterima \\
\hline Kinerja & & & & & & & \\
\hline Employee Engagement terhadap & & & & 0,153 & 1,665 & 0,099 & $\mathrm{H}_{4}$ Diterima \\
\hline Kinerja & & & & & & & \\
\hline $\begin{array}{l}\text { Komitmen Organisasional } \\
\text { terhadap Kinerja }\end{array}$ & & & & 0,751 & 9,591 & 0,000 & $\mathrm{H}_{5}$ Diterima \\
\hline
\end{tabular}

\section{Komitmen Organisasional Tidak Memediasi Pengaruh Karakteristik Pekerjaan terhadap Kinerja}

Komitmen organisasional tidak memediasi pengaruh karakteristik pekerjaan terhadap kinerja yang ada di PT Jati Luhur Agung Semarang. Hasil penelitian ini menunjukkan bahwa dengan karakteristik pekerjaan yang merupakan sifat khas yang melekat pada suatu pekerjaan yang meliputi keragaman tugas, keragaman keahlian atau skill, identitas tugas dan otonomi berpengaruh langsung terhdap kinerja. Organisasi perlu memahami bagaimana karakteristik pekerjaan yang diperlukan oleh organisasi dan juga para karyawannya sehingga dapat memuaskan karyawannya. 


\section{Komitmen Organisasional Memediasi Pengaruh Employee Engagement terhadap Kinerja}

Komitmen organisasional memediasi pengaruh employee engagement terhadap kinerja yang ada di PT Jati Luhur Agung Semarang. Hasil penelitian ini menunjukkan bahwa semakin baik dari employee engagement pada karyawan akan meningkatkan komitmen organisasional dan selanjutnya berdampak pada peningkatan kinerja karyawan. Penelitian ini mendukung temuan Hakim (2018) yang memberikan hasil bahwa semakin baik dari employee engagement pada karyawan akan meningkatkan komitmen organisasi dan berdampak pada peningkatan kinerja karyawan.

\section{SIMPULAN DAN SARAN}

Dari data yang didapatkan dan analisis yang telah dilakukan dalam penelitian ini, maka yang dapat disimpulkan adalah karakteristik pekerjaan tidak berpengaruh terhadap komitmen organisasional. Hal ini bermakna jika karakteristik pekerjaan karyawan kurang diperhatikan, maka komitmen organisasional karyawan tersebut akan menurun. Employee engagement berpengaruh positif dan signifikan terhadap komitmen organisasional yang bermakna semakin tinggi employee engagement maka akan semakin tinggi komitmen organisasional. Karakteristik pekerjaan berpengaruh berpengaruh positif dan signifikan terhadap kinerja. Hal ini bermakna bahwa semakin tinggi karakteristik pekerjaan maka akan semakin tinggi komitmen organisasional. Employee engagement berpengaruh positif dan signifikan terhadap kinerja. Hal ini menjelaskan jika employee engagement diperhatikan, maka kinerja karyawan tersebut akan meningkat. Komitmen organisasional berpengaruh positif dan signifikan terhadap kinerja yang bermakna bahwa semakin tinggi komitmen organisasional maka akan semakin tinggi kinerja. Karyawan yang memiliki komitmen dan kesetiaan yang tinggi akan bekerja dengan optimal demi mencapai kinerja yang baik. Komitmen organisasional mampu memediasi pengaruh employee engagement terhadap kinerja. Hal ini bermakna bahwa untuk meningkatkan kinerja, lebih efektif melalui komitmen organisasional daripada secara langsung.

Keterbatasan dalam penelitian ini yaitu karakteristik pekerjaan dan employee engagement hanya mampu menjelaskan komitmen organisasional sebesar 31,9\%. Penelitian yang akan datang tentang komitmen organisasional dimasukkan variabel lain seperti kompensasi, sistem evaluasi kinerja, budaya organisasi, dan lainnya. Penelitian ini hanya memotret kondisi sesaat pada saat penelitian dilakukan. Organisasi diharapkan mampu meningkatkkan komitmen organisasional dalam meningkatkan kinerja dengan cara memberikan pekerjaan yang menantang dan melibatkan pegawai dalam membahas masalah-masalah organisasi.

\section{REFERENSI}

Affandy, R. E. (2016). Pengaruh Karakteristik Pekerjaan terhadap Kinerja Pegawai dengan Motivasi dan Lingkungan Kerja sebagai Variabel Pemoderasi (Studi pada Pegawai Divisi Sarana PT. Kereta Api Indonesia (Persero) Daop 8 Surabaya). Journal of Innovation in Business and Economics, 7(2), 77-86. Albdour, A. A., \& Altarawneh, I. I. (2014). Employee engagement and organizational commitment: Evidence from Jordan. International journal of business, 19(2), 192-212.

Allen, N. J., \& Meyer, J. P. (1990). The measurement and antecedents of affective, continuance and normative commitment to the organization. Journal of occupational psychology, 63(1), 1-18.

Ananda, S. S., \& Sunuharyo, B. S. (2018). Pengaruh Karakteristik Individu Dan Karakteristik Pekerjaan Terhadap Kinerja Karyawan Dengan Variabel Mediator Motivasi Kerja Karyawan 
(Studi Pada Karyawan PT Petrokimia Gresik). Jurnal Administrasi Bisnis, 58(1), 67-76.

Armstrong, M. (2012). Armstrong's handbook of management and leadership: developing effective people skills for better leadership and management. Kogan Page Publishers.

Astuti, E., \& Khoirunnisa, R. M. (2018). Pengaruh Employee Engagement, Komitmen Organisasi, Dan Kepemimpinan Transformasional Terhadap Kesiapan Untuk Berubah (Readiness For Change) Pada Karyawan Universitas Ahmad Dahlan. Jurnal Fokus, 8(1), 47-66.

Atmojo, M. (2015). The influence of transformational leadership on job satisfaction, organizational commitment, and employee performance. International research journal of business studies, 5(2), 113 128.

Cardoso Gomes, F. (1995). Manajemen Sumber Daya Manusia. Yogyakarta: Andi.

Ekayanti, W., Widjajani, S., \& Budiyanto, B. (2019). Pengaruh Karakteristik Personal dan Karakteristik Pekerjaan terhadap Komitmen Organisasional Perawat. Jurnal Maksipreneur: Manajemen, Koperasi, dan Entrepreneurship, 8(2), 181-190.

Gibson, J. L. (2000). Organisasi, Perilaku, Struktur dan Proses, Edisi ke-5, Cetakan ke-3. Jakarta: Penerbit Erlangga.

Hakim, M. L. (2018). Pengaruh Employee Engagement dan Pelatihan Terhadap Kinerja Karyawan Melalui Komitmen Organisasi Sebagai Variabel Intervening Di RSU Aisyiyah Purworejo. Skripsi. Universitas Islam Indonesia Yogyakarta.

Hanaysha, J. (2016). Testing the effects of employee engagement, work environment, and organizational learning on organizational commitment. Procedia-Social and Behavioral Sciences, 229, 289-297.
Haryanto, R., Fathoni, A., \& Minarsih, M. M. (2018). Pengaruh Karakteristik Pekerjaan, Employee Engagement dan Motivasi terhadap Komitmen Organisasi dengan Kepuasan Kerja sebagai Intervening pada PT. Eka Farma Di Semarang. Journal of Management, 4(4).

Heriyawan, M. S. \& Setyowati, W. (2015). Pengaruh Karakteristik Pekerjaan dan Pemberdayaan terhadap Kinerja Pegawai dengan Mediasi Komitmen Organisasional (Studi pada Politeknik Ilmu Pelayaran Semarang). Proceeding SENDI_U.

Huang, C. J., Chen, M. L., Huang, C. Y., \& Ma, K. C. (2016). Centralization extent and organizational commitment of part-time workers in Taiwan's convenience chain stores. International Journal of Organizational Innovation (Online), 8(3), 248.

Jones, R. (2018). The Relationship of Employee Engagement and Employee Job Satisfaction to Organizational Commitment. Walden Dissertations and Doctoral Studies Collection. Walden University Scholar Works.

Joushan, S. A., Syamsun, M., \& Kartika, L. (2015). Pengaruh Budaya Organisasi dan Employee Engagement terhadap Kinerja Karyawan pada PT PLN (Persero) Area Bekasi. Jurnal Aplikasi Manajemen, 13(4), 697-703.

Kahn, W. A. (1990). Psychological conditions of personal engagement and disengagement at work. Academy of management journal, 33(4), 692724.

Kaswan, K. (2019). Manajemen Sumber Daya Manusia Strategis. Yogyakarta: CV Andi Offset.

Martono, S., Dirgantoro, G. S., \& Ranihusna, D. (2017). Pengaruh karakteristik pekerjaan, budaya organisasi, dan kepuasan kerja pada komitmen organisasional. Jurnal 
studi manajemen organisasi, 14(2), 11.

Mulyani, S., \& Soliha, E. (2014). Pengaruh Karakteristik Pekerjaan dan Motivasi terhadap Komitmen Organisasional serta Dampaknya terhadap Kinerja Guru (Studi di SMP Negeri 21 dan SMP Negeri 26 Semarang). Performance, 20(2), 46-71.

Mulyanto, J. C., Chandra, L., \& Nugroho, A. (2014). Analisa Pengaruh karakteristik pekerjaan terhadap kepuasan dan kinerja karyawan di hotel D'season Surabaya. Jurnal Hospitality dan Manajemen Jasa, 2(2), 312-325.

Oldham, G. R., \& Hackman, J. R. (2005). How Job Characteristics Theory Happened. In K. G. Smith, \& M. A. Hitt (Eds.), Great minds in management: The process of theory development (pp. 151-170). New York: Oxford University Press.

Oldham, G. R., \& Hackman, J. R. (2010). Not what it was and not what it will be: The future of job design research. Journal of organizational behavior, 31(2-3), 463-479.

Pradana, O. A., \& Swasto, B. (2014). Pengaruh motivasi kerja dan komitmen organisasional terhadap kinerja karyawan (Studi pada karyawan bagian HRD PT. Arthawena Sakti Gemilang Malang). Jurnal Administrasi Bisnis, 7(2).

Purwanto, B. H., \& Soliha, E. (2017). Pengaruh karakteristik pekerjaan dan kompetensi terhadap kinerja melalui komitmen organisasional. Jurnal Manajemen, 21(2), 227-240.

Riyanto, A. \& Rozak, H. A. (2016). Pengaruh Kompetensi dan Karakteristik Pekerjaan terhadap Kinerja Pegawai dengan Komitmen Organisasional sebagai Mediasi
(Studi Pada Pegawai Dinas Perdagangan Kota Semarang). Jurnal Mahasiswa Pasca Sarjana Universitas Stikubank.

Robbins, S.P. \& Judge T.A. (2008). Perilaku Organisasi, Buku 2 (D. Angelica, Trans.). Jakarta: Salemba Empat.

Schaufeli, W. B., \& Bakker, A. B. (2004). UWES-Work Engagement Scale: Test manual. Unpublished manuscript. Department of Psychology, Utrecht University.

Scott, W. A. (2005). The elements of UML 2.0 Style. Press Syndicate of the Cambridge University.

Siswono, S. D. (2016). Pengaruh employee engagement terhadap kinerja karyawan di rodex travel surabaya. Agora, 4(1), 458-466.

Simamora, H. (2004). Manajemen Sumber Daya Manusia, Edisi Ke-3. Yogyakarta: Badan Penerbitan STIE YKPN.

Singh, J., Verbeke, W., \& Rhoads, G. K. (1996). Do organizational practices matter in role stress processes? A study of direct and moderating effects for marketing-oriented boundary spanners. Journal of marketing, 60(3), 69-86.

Suparyanto, S., \& Wahyudi, A. (2011). Pengaruh Komitmen Organisasi Terhadap Kinerja Pegawai Dengan Kepuasan Kerja Sebagai Variabel Intervening. Jurnal Manajemen Sumber Daya Manusia, 3(2), 132144.

Winowoda, D. A., (2018). Pengaruh Employee Engagement dan Kepuasan Kerja terhadap Kinerja Karyawan melalui Komitmen Organisasi sebagai Variabel Intervening di Hotel Grand Inna Malioboro Yogyakarta. Skripsi. Universitas Islam Indonesia Yogyakarta. 